\title{
E a justiça aqui tão perto? As transformações no acesso ao direito e à justiça
}

Justice at Hand? Transformations in the Access to Law and Justice

La justice est-elle si proche? Les transformations dans l'accès au droit et à la justice

João Pedroso, Catarina Trincão e João Paulo Dias

\section{OpenEdition}

\section{Journals}

Edição electrónica

URL: http://journals.openedition.org/rccs/1181

DOI: $10.4000 /$ rccs. 1181

ISSN: 2182-7435

\section{Editora}

Centro de Estudos Sociais da Universidade de Coimbra

Edição impressa

Data de publição: 1 Maio 2003

Paginação: 77-106

ISSN: 0254-1106

\section{Refêrencia eletrónica}

João Pedroso, Catarina Trincão e João Paulo Dias, « E a justiça aqui tão perto? As transformações no acesso ao direito e à justiça », Revista Crítica de Ciências Sociais [Online], 65 | 2003, colocado online no dia 01 outubro 2012, criado a 30 abril 2019. URL : http://journals.openedition.org/rccs/1181 ; DOI : $10.4000 /$ rccs. 1181

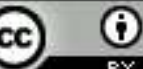




\section{JOÃO PEDROSO \\ CATARINA TRINCÃO \\ JOÃO PAULO DIAS}

\section{E a justiça aqui tão perto? As transformações no acesso ao direito e à justiça}

Apresenta-se uma síntese da investigação sobre o acesso ao direito e à justiça realizada no âmbito do Observatório Permanente da Justiça Portuguesa, começando por se analisar a evolução dos sistemas de promoção do acesso ao direito e à justiça, no apogeu e no declínio do Estado-Providência, passando pelo apoio jurídico a pobres, a protecção dos interesses difusos e a resolução alternativa de litígios. Após uma breve análise da acção recente da União Europeia e do Conselho da Europa, atenta-se nas transformações do acesso ao direito e à justiça em França, Inglaterra e Espanha e estuda-se a evolução do regime do apoio judiciário em Portugal, de 1970 até aos nossos dias. Por último, procede-se à análise do impacto das recentes reformas do regime do apoio judiciário em Portugal e da acção da rede das entidades públicas e privadas que prestam informação, consulta jurídica e patrocínio jurídico em Portugal.

\section{Introdução}

Mauro Cappelletti e Brian Garth (1978) coordenaram, nos finais dos anos setenta, um grande projecto de investigação sobre o acesso ao direito e à justiça em diversos países, no qual nos propuseram dois caminhos analíticos. O primeiro identificava o acesso ao direito e à justiça com a igualdade no acesso ao sistema judicial e/ou à representação por advogado num litígio. O segundo, mais abrangente, encarava o acesso ao direito como a garantia de efectividade dos direitos individuais e colectivos. É esta visão mais ampla que aqui privilegiamos. Os nossos direitos só são efectivos se tivermos consciência deles e, na eventualidade de nos considerarmos lesados, pudermos recorrer a uma instância ou a uma entidade à qual se reconheça legitimidade para dirimir esse nosso litígio com o lesante.

\footnotetext{
${ }^{1} \mathrm{O}$ presente artigo é subsidiário da investigação e da reflexão incorporadas no relatório do Observatório Permanente da Justiça, O Acesso ao Direito e à Justiça: um direito fundamental em questão (Pedroso, Trincão e Dias, 2002).
} 
Os estudos realizados pela sociologia judiciária revelam que os obstáculos ao acesso efectivo à justiça por parte das classes populares são de três tipos: económicos, sociais e culturais. ${ }^{2}$ Os custos económicos compreendem, nomeadamente: preparos e custas judiciais; honorários de advogados e de outros profissionais como, por exemplo, peritos; gastos com transporte e outros e, ainda, uma série de custos de oportunidade com valor económico, para além dos custos resultantes da morosidade (Santos et al., 1996: 486). ${ }^{3}$ Todos estes custos tornam a justiça dispendiosa e proporcionalmente mais cara para as acções de pequeno valor, por alguns destes custos serem rígidos, o que vitimiza as classes populares, dado que é precisamente neste tipo de acções que tendem a intervir. Quanto mais baixo é o estrato sócio-económico do cidadão, menos provável é que conheça o direito ${ }^{4}$ ou um advogado, menos provável é que saiba onde, como e quando contactar o advogado, e maior é a distância geográfica entre o lugar onde vive ou trabalha e a zona da cidade onde se encontram os escritórios de advocacia e os tribunais.

No entanto, estudos mais recentes, como os inquéritos de opinião sobre as representações sociais dos tribunais, o direito e a litigiosidade (Santos et al., 1996: 503-684; Santos et al., 2003), permitem-nos concluir que, na sociedade portuguesa, os cidadãos têm um bom conhecimento do direito vigente, mas tal conhecimento não se reflecte, necessariamente, no crescimento da procura dos tribunais. Acresce que esses estudos revelam que existe uma percentagem significativa da população (cerca de $20 \%$ em algumas matérias) que não conhece o direito e, consequentemente, tem mais dificuldades em reconhecer as possibilidades de reparação jurídica de problemas que a afectem.

A discriminação social no acesso à justiça é, assim, um fenómeno muito complexo, já que, para além das condicionantes económicas, sempre mais óbvias, envolve condicionantes sociais e culturais resultantes de processos de socialização e de interiorização de valores dominantes muito difíceis de transformar.

Nesta linha de ideias, considera-se que a organização da justiça e a tramitação processual não podem ser reduzidas à sua dimensão técnica socialmente neutra - como era comum serem concebidas pela teoria processua-

\footnotetext{
2 Sobre os diferentes tipos de barreiras de acesso à justiça cf., entre outros, Macdonald (1984).

3 Sobre os custos da litigação e sua influência na função da procura de tutela judicial, assim como na gestão da oferta, cf. Santos et al. (1996: cap. II).

${ }^{4}$ Caplowitz (1963), por exemplo, concluiu que quanto mais baixo é o estrato social do consumidor, maior é a probabilidade de que desconheça os seus direitos no caso de compra de um produto defeituoso (apud Santos, 1994).
} 
lista -, devendo investigar-se as funções sociais desempenhadas e, em especial, o modo como as opções técnicas no seu seio veiculam opções a favor ou contra interesses sociais divergentes ou mesmo antagónicos (Santos, 1994).

A atitude positiva e promocional do Estado no domínio do acesso é tanto mais importante quanto menor for a capacidade de resposta da sociedade. Acresce que também neste âmbito a discrepância entre o quadro jurídico-institucional e as práticas sociais se tem mantido, em Portugal, num nível muito elevado, traduzindo-se num modelo jurídico-institucional semelhante ao dos países centrais, enquanto as práticas sociais se encontram aquém do que está estabelecido legalmente (Santos, 1985; 1993; 1995).

Assim, partindo da hipótese geral de que o acesso ao direito depende da acção positiva da sociedade e do Estado, é nosso propósito analisar os meios de facilitação do acesso dos cidadãos ao direito e à justiça. Garantir o acesso ao direito é assegurar que os cidadãos conhecem os seus direitos, que não se resignam quando estes são lesados e que têm condições de vencer os custos de oportunidade e as barreiras económicas para aceder livremente à entidade que consideram mais adequada para a resolução do litígio - seja uma terceira parte da comunidade, uma instância formal não judicial ou os tribunais judiciais.

\section{As três vagas do acesso ao direito e à justiça: 0 apoio jurídico a pobres, a protecção dos interesses difusos e a resolução alternativa de litígios}

De modo a eliminar, ou, pelo menos, a atenuar, os obstáculos referidos, vários países, após a Segunda Guerra Mundial, procederam a reformas legais e de transformação das profissões jurídicas, com o objectivo de facilitarem o acesso à justiça. Desenvolveu-se um movimento de reformas legais e de programas de apoio aos cidadãos que passou por várias fases. A primeira vaga teve início em 1965, e consistiu num movimento caracterizado pela defesa e pela promoção de apoio judiciário aos cidadãos de menores rendimentos, designadamente através dos Neighborhood Offices (gabinetes jurídicos de vizinhança). ${ }^{5}$ A segunda fase estendeu este movimento, a partir de 1970, à promoção de representação dos interesses difusos, com o desenvolvimento das public interest law firms (a advocacia de defesa dos consumidores, ambiente, etc.), subsidiadas pelo Estado, comunidades e

\footnotetext{
5 A reforma começou nos EUA, em 1965, com o Legal Service Program of the Office of Economic Opportunity (OEO). Em 1972, a França substituiu o seu sistema de apoio judiciário do século XIX, baseado em serviços gratuitos prestados pela Ordem dos Advogados. Em Maio de 1972, a Suécia implementa o novo programa. Dois meses mais tarde, o English Legal Advice Assistance Act, expandiu a rede inglesa de 1949, sobretudo na vertente de informação jurídica.
} 
fundações. A terceira vaga iniciou-se ainda nos anos setenta, colocando a ênfase na mudança das instituições de resolução de litígios, isto é, na criação de meios alternativos de resolução de litígios menos formais que os tribunais, os chamados ADR - Alternative Dispute Resolution (Resolução Alternativa de Litígios - RAL). Segundo Cappelletti (1981: 5), o acesso à justiça caminhará para uma situação de integração das três fases, não havendo, por isso, entre elas, uma relação de substituição sucessiva, mas antes de coexistência, mantendo cada uma a sua função específica.

A defesa dos interesses colectivos assumiu uma pluralidade de formas. Em primeiro lugar, gabinetes jurídicos e de advogados especializados ao serviço de sindicatos, associações ou fundações, designadamente ambientalistas, de consumidores e culturais. Em segundo lugar, os juristas e advogados do Estado, que se especializam na promoção e na defesa dos direitos colectivos. Em terceiro lugar, advogados que, nos seus escritórios privados, se dedicam, na totalidade ou em parte do seu tempo, por razões altruístas ou profissionais, a defender causas de interesse colectivo (vítimas da poluição, do tabaco, etc.). Por último, refira-se que, em alguns países como Portugal, foi atribuída legitimidade ao Ministério Público para promover e intentar acções judiciais relativamente à defesa de interesses colectivos, como seja a defesa do ambiente ou dos consumidores.

Os tribunais apenas regulam uma diminuta parcela de todos os conflitos que poderiam aceder aos tribunais, e uma parte mais ínfima ainda do total dos litígios produzidos na sociedade (Galanter, 1984: 153; Santos et al., 1996: 49). O cerne do acesso à justiça não é, em consequência, possibilitar que todos vão a tribunal, mas sim que se realize a justiça no contexto em que se inserem as partes, salvaguardada a imparcialidade de decisão e a igualdade efectiva das partes perante esse meio de administração da justiça.

Os Estados e as sociedades estão a construir um novo sistema de resolução de litígios no qual se reconfiguram as funções do Estado e da sociedade civil, se desenvolvem as parcerias entre o público, a comunidade e, eventualmente, o mercado, e no qual se assume um novo modelo de justiça, ou seja, um sistema integrado de resolução de litígios, em que a pluralidade dos ADR (RAL) tanto pode constituir alternativa aos tribunais judiciais (resolver litígios que os tribunais também dirimem), um seu complemento (para os litígios que nunca chegariam a tribunal) ou, ainda, um seu substituto (a transferência de competências de resolução de litígios dos tribunais para estes meios).

O novo sistema integrado de resolução de litígios deve ter, como consequência, a promoção pelo Estado duma política pública de justiça, que 
inclui os tribunais judiciais e que reconhece também aos meios não judiciais legitimidade para dirimir litígios. A informalização da justiça e a desjudicialização, incluindo todo o movimento $\mathrm{ADR}$, constituem, assim, caminhos da reforma da administração da justiça, desde que defendam a igualdade das partes e que promovam o acesso ao direito, dado que só esta multiplicidade de processos pode tornar a justiça mais democrática (Pedroso, Trincão e Dias, 2001: 53).

\section{Os modelos puros e mistos de apoio judiciário: assistência judiciária gratuita, advocacia convencionada e advocacia pública}

No imediato pós-guerra, vigorou, na maioria dos países, um sistema de assistência judiciária gratuita organizado pelas Ordens dos Advogados (Cappelletti e Garth, 1978: 22ss.; Blankenburg, 1984). Os inconvenientes deste sistema eram muitos e rapidamente foram denunciados. A qualidade dos serviços jurídicos era baixíssima, uma vez que, ausente a motivação económica, a distribuição acabava por recair em advogados sem experiência e, por vezes, ainda não plenamente profissionalizados, em geral sem qualquer dedicação à causa. Os critérios de elegibilidade eram estritos e a assistência limitava-se aos actos em juízo, estando excluída a consulta jurídica e a informação sobre os direitos. A denúncia das carências deste tipo de sistema privado e caritativo implicou que, na maioria dos países, fosse sendo substituído por um sistema político e assistencial organizado ou subsidiado pelo Estado (Santos, 1994: 149).

Em geral, e de forma comum a todos os países, este movimento de legal aid transformou a advocacia. A par da advocacia tradicional, surgiram, de modo tímido, a advocacia com fins sociais e a advocacia pública. Estas duas novas faces da advocacia surgem inseridas em movimentos socialmente comprometidos, pretendendo a primeira, unicamente, resolver os problemas jurídicos dos mais carenciados a título individual (defesa de pobres) e visando a segunda já defendê-los, como referimos, numa perspectiva colectiva (advogados de sindicatos, associações), isto é, defender os interesses colectivos dos cidadãos no sentido de uma public interest advocacy. ${ }^{6}$

Em contraponto aos sistemas caritativos, desenvolveram-se dois modelos alternativos: o da advocacia convencionada e o da advocacia pública.

\footnotetext{
${ }^{6}$ Blankenburg e Cooper (1982: 4) referem, ainda, como exemplo da advocacia política na antiga República Federal da Alemanha, a luta que foi mantida nos tribunais administrativos contra os Berufverbote, ou seja, as interdições profissionais de trabalhar na função pública a que o Estado sujeitava certos cidadãos, por serem, por exemplo, pacifistas, ecologistas, ou membros de associações ou de partidos políticos de esquerda. Cooper (1991) é uma interessante fonte de informação sobre Public interest law.
} 
O sistema de advocacia convencionada, conhecido por judicare, foi criado em Inglaterra em 1949 (aperfeiçoado em 1974 e 1988), de acordo com o qual o cidadão elegível, atendendo aos seus limites de rendimento, escolhe um advogado de entre os que se inscreveram numa lista para prestação desses serviços (Sousa, 1993:39-45). A remuneração do advogado é assegurada pelo Estado, segundo os preços correntes no mercado dos serviços advocatícios.

O modelo do Public Salaried Attorney (advocacia pública) com origem em 1965, aspirava a objectivos diferentes do sistema judicare, graças ao Legal Services Program do gabinete de Economic Opportunity dos EUA, tido como a vanguarda da guerra à pobreza. Os serviços legais eram assegurados nos neighborhood law offices por advogados pagos pelo Governo e encarregados de zelar pelos interesses das classes mais vulneráveis. Os gabinetes eram pequenos e estrategicamente localizados junto de comunidades carenciadas, com vista a facilitar o contacto com os mais desfavorecidos, a derrubar as barreiras sociais e a alertar as pessoas para os seus "velhos" e "novos" direitos.

Nos anos oitenta, o problema da insuficiência de orçamento ganhou importância à medida que se tomou consciência das dificuldades existentes no modelo da advocacia pública na defesa dos mais desfavorecidos. Essas dificuldades eram de três tipos: a existência de um número excessivo de conflitos a tratar, pelo que a procura desses serviços jurídicos aumenta à medida que tal necessidade pode ser satisfeita; a necessidade de despender menos tempo com cada caso; a inexperiência e a complexidade, tanto jurídica como emocional, dos problemas, bem como a dificuldade de entendimento entre os advogados e os seus representados e a impaciência e a hostilidade de alguns tribunais. A conjugação de todos estes factores levou à prática de uma actividade jurídica de rotina, de tal forma que o trabalho se tornou, necessariamente, de fraca qualidade (Bellow, 1984: 70).

Michael Zander (1984: 41), que partiu do sistema inglês, baseando-se no relatório da Royal Commission on Legal Services de 1979, aponta as vantagens e os inconvenientes do judicare system. Entre as vantagens do judicare system, salienta: a) o facto de os advogados privados terem competências que podem ser colocadas ao serviço dos clientes com vulnerabilidades sociais, desde que para o efeito sejam pagos; b) a circunstância de os advogados profissionais liberais existirem em numerosas cidades de província, o que permite, de forma eficaz e cómoda, o recurso aos seus serviços dado que, se não houvesse tais escritórios, teria de ser criada uma densa rede de staff offices para os substituir; c) o facto de, desde que remunerados de forma adequada, o recurso a estes profissionais pôr ao dispor dos mais 
desfavorecidos os serviços de juristas experientes, o que não acontece no staff system, em que o apoio judiciário é assegurado por juristas inexperientes.

No entanto, os profissionais liberais dificilmente acreditam que o apoio jurídico possa conduzir a reformas no direito e preferem não se ocupar dos interesses de grupos de cidadãos, dado que só se sentem à vontade em assuntos tradicionais. O sector público pode, em parte, diminuir tal inconveniente, ao estabelecer centros de apoio judiciário nas zonas mais desfavorecidas, tendo estes uma actividade na reforma do direito, na protecção de grupos sociais e na educação jurídica. ${ }^{7}$

$\mathrm{Na}$ defesa de um sistema misto de apoio judiciário, Michael Zander defende que o âmbito do apoio judiciário deve ser o mais abrangente possível, pois deve abarcar matérias processuais civis e penais, a prestação de informação e a assistência judiciária. Deve, ainda, chegar ao maior número possível de pessoas, não devendo ser impostas excessivas exigências quanto aos seus rendimentos, ao mesmo tempo que não deve comportar um princípio de inteira gratuitidade. ${ }^{8}$

\section{O acesso ao direito e à justiça no apogeu e na crise do Estado- -Providência}

As reformas e o desenvolvimento dos sistemas de acesso ao direito e à justiça estão em estreita relação com a consolidação do Welfare State. Assistiu-se a um desenvolvimento dos direitos, com a afirmação, para além dos direitos cívicos e políticos, dos direitos sociais, económicos e culturais ${ }^{9}$ e, ainda, dos novos direitos, como a defesa do ambiente ou dos consumidores.

Após o fim da Segunda Grande Guerra, assistimos, assim, a diversas transformações no sistema de acesso ao direito e à justiça. A primeira grande mudança ocorreu na evolução das soluções caritativas para esquemas financiados pelo Estado. A inadequada caridade das profissões legais foi substituída por regimes de âmbito nacional, de espectro largo, financiados publicamente ou através de esquemas mistos. Enquanto os esquemas caritativos

\footnotetext{
${ }^{7}$ Em alguns sistemas, o beneficiário de apoio judiciário escolhe o jurista que lhe prestará assistência, de uma lista existente no tribunal ou em organismos de apoio judiciário; em outros sistemas, o cliente pode escolher, ele próprio, qualquer jurista que aceite patrociná-lo. Este solução é preferível. Porém, se o sector público está interdito de tratar algumas categorias de assuntos - como foi recomendado em Inglaterra - a escolha do jurista é limitada.

${ }^{8} \mathrm{Na}$ maioria dos países, o sistema funciona só a favor dos muito carenciados. Apenas o sistema sueco permite que a grande maioria dos cidadãos beneficie do apoio judiciário.

9 Em 1944, a mensagem anual do Presidente Roosevelt foi muito precisa, ao enumerar os novos direitos - os direitos sociais - fundados nas necessidades mais dos que na propriedade, opondo-se alguns aos direitos tradicionais.
} 
ajudavam só os cidadãos mais pobres para um pequeno número de casos matrimoniais e criminais, os novos esquemas de financiamento público e/ou mistos ofereciam um largo leque de serviços para os mais variados problemas legais dos cidadãos mais vulneráveis socialmente e, em algumas sociedades, também para os "não-pobres". Estes regimes de acesso ao direito e à justiça recorriam, com frequência, aos serviços de advogados assalariados, em paralelo aos serviços jurídicos dos profissionais liberais (Cappelletti et al., 1978).

Entre os anos cinquenta e oitenta do século XX, foram efectuadas reformas similares do regime jurídico e dos meios de acesso ao direito e à justiça no Reino Unido, Holanda, EUA, Canadá, Suécia e Austrália, enquanto, em outras sociedades, incluindo a França, se introduziram também reformas, ainda que mais limitadas. Reinava o optimismo, o que foi reforçado pelo grande estudo de Cappelletti et al. (1978), em que se identificam as três referidas vagas globais da reforma do acesso ao direito e à justiça, envolvendo, não só o apoio judiciário, mas também uma completa panóplia de instituições e de dispositivos pessoais e processuais usados nos processos e também para prevenir litígios nas sociedades modernas.

Este sentido começou a inverter-se nos anos oitenta e noventa, quando os governos "perderam a fé" nos programas do Estado-Providência e começaram a cortar nos orçamentos do acesso ao direito e à justiça (Regan et al., 1999). O declínio dos regimes do acesso ao direito e à justiça, nos anos oitenta e noventa, está bem documentado na literatura sócio-jurídica (Goriely e Paterson, 1996). Apesar do crescimento da procura do direito e da justiça na maior parte das sociedades, os requisitos de elegibilidade e de acesso ao sistema de apoio legal tornaram-se mais restritivos e foi introduzida ou desenvolvida a obrigatoriedade das contribuições dos utentes para o pagamento parcial (ou total) do custo dos seus casos. As orientações políticas dos diversos governos foram no sentido de restringir o espectro de casos para os quais o apoio judiciário estava disponível, limitando-o progressivamente, nos países onde foi mais desenvolvido, aos casos criminais. Os critérios de elegibilidade para se ter direito aos meios de acesso ao direito e à justiça dos anos noventa retomaram os esquemas caritativos anteriores à Segunda Guerra Mundial.

A este pessimismo e declínio dos regimes e meios de acesso ao direito e à justiça dos anos oitenta e noventa, sucedeu, no final do século XX e início do século XXI, um discurso político e legislativo de desenvolvimento e de consolidação de todos os meios que permitam aos cidadãos aceder ao direito e à resolução de litígios, designadamente na Europa, como analisaremos no ponto seguinte. 


\section{A Europa e as transformações recentes dos regimes legais de acesso ao direito e à justiça: uma breve síntese}

$\mathrm{Na}$ Europa, o debate actual e as transformações dos sistemas de acesso ao direito e à justiça desenvolvem-se por impulso das instituições europeias, em sentido amplo, bem como das reformas legais, institucionais e dos movimentos sociais em cada um dos Estados e respectivas sociedades.

A acção das instituições europeias é constituída, essencialmente, por soft law não vinculativa para os Estados, mas com impacto visível nas transformações dos seus regimes jurídicos e das suas instituições. As reformas dos regimes jurídicos do acesso ao direito e à justiça dos diversos Estados são profundas. No entanto, no presente artigo, limitar-nos-emos a uma breve referência a três exemplos de modelos diferentes de reforma legal, que vão de uma visão plural do acesso ao direito, em França, ao judicare em acção, na Inglaterra e no País de Gales e, ainda, aos regimes de assistência judiciária gratuita, como o de Espanha e o de Portugal.

\subsection{A acção das instituições europeias: $O$ acesso à justiça entre os direitos humanos e a soft law}

$\mathrm{O}$ acesso ao direito e à justiça é um direito humano consagrado nas principais cartas internacionais dos direitos humanos, nomeadamente na Declaração Universal dos Direitos Humanos, proclamada em 1948 pela Organização das Nações Unidas, e na Convenção Europeia dos Direitos do Homem, aprovada em 1950 pelo Conselho da Europa. O artigo 6. ${ }^{\circ}, \mathbb{\$}$ desta Convenção, no que se refere à justiça criminal, tem sido interpretado pelo Tribunal Europeu dos Direitos Humanos como um direito a assistência jurídica em processos cíveis quando assim o exijam os interesses da justiça. ${ }^{10}$

A partir do Conselho Europeu de Tampere (Outubro de 1999), o acesso ao direito e à justiça aparece, finalmente, autonomizado na União Europeia como uma medida prioritária, estabelecendo-se, inclusivamente, um padrão mínimo de apoio judiciário para que os cidadãos tenham direito a um julgamento justo dentro do espaço comum europeu. O Livro Verde da Comissão Europeia sobre a assistência judiciária civil (2000) propõe, entre outras medidas, a prestação de conselhos jurídicos gratuitos ou a baixo custo; a representação em tribunal por um advogado; e a isenção parcial ou total de outras despesas, designadamente de custas judiciais.

\footnotetext{
${ }^{10}$ Cf. o acórdão do Tribunal Europeu dos Direitos Humanos n.os 27715/95 e 30209/96, da IV secção, de 20 de Junho de 2002, Berlinski contra Polónia, referente ao atraso na nomeação de um advogado no âmbito do apoio judiciário (http://www.echr.coe.int/Fr/FDocs/ OBJET\%20DES\%20 AFFAIRES2002.pdf).
} 
Em 2002, a Comissão Europeia publicou o Livro Verde sobre os modos alternativos de resolução de litígios em matéria civil e comercial. A União Europeia está, assim, a desenvolver esforços para facilitar o acesso à justiça, através da criação de um sistema de informação de fácil acesso, assegurado por uma rede de autoridades nacionais competentes. Tais esforços inserem-se nos mecanismos já desenvolvidos, com o objectivo de criar um espaço europeu de justiça baseado no princípio do reconhecimento mútuo.

Por seu turno, o Conselho da Europa, primeiro em 1978, através da Resolução n. ${ }^{\circ} \mathrm{R}(78) 8$ (assistência judiciária e consulta jurídica) e, depois, em 1993, através da Recomendação n. ${ }^{\circ} \mathrm{R}$ (93)1, demonstrou preocupar-se com o acesso efectivo ao direito e à justiça das pessoas em situação de grande pobreza. O Comité de Ministros recomendava então aos governos dos estados membros que facilitassem às pessoas em situação de grande pobreza o acesso efectivo ao direito ("o direito ao direito"), o acesso efectivo aos modelos para-judiciários de resolução de conflitos e aos tribunais.

O Conselho da Europa debateu o acesso ao direito e à justiça na 23. ${ }^{a}$ Conferência de Ministros da Justiça Europeus (Londres, 2000), na qual a qualidade da justiça e a relação custo-eficácia foram os temas dominantes. Entre as medidas preconizadas, destacam-se: os aspectos relativos à introdução de um sistema moderno de aconselhamento e de apoio jurídico; o apoio, aconselhamento e assistência jurídico-legal como uma condição para a protecção e promoção dos Direitos Humanos; a possibilidade de o aconselhamento e apoio jurídico serem prestados, não apenas por advogados, mas também por outros profissionais, desde que seja assegurada a qualidade do serviço; a fixação de um sistema de apoio jurídico na Europa que tenha em conta a situação económica dos litigantes e as suas probabilidades de êxito; a necessidade de encontrar um ponto de equilíbrio financeiro no triângulo Estado/beneficiários/advogados, procurando assegurar a qualidade e a credibilidade do apoio e assistência jurídica, considerando os custos do sistema como um todo.

\subsection{A França: uma visão plural de acesso ao direito e à justiça}

A França, de entre os países analisados, apresenta o modelo mais complexo e mais completo. ${ }^{11}$ A nova lei de 1998 de acesso ao direito e à justiça vem aprofundar o caminho seguido pela lei de 1991, nomeadamente na consideração de uma visão plural do acesso ao direito e à justiça e de um sistema integrado de resolução de litígios de que os tribunais são uma parte do

\footnotetext{
${ }^{11}$ Este modelo foi alvo de reformas intercalares em 1972, 1991 e 1998. Cf. os documentos inseridos no site do Ministério da Justiça francês (http://www.justice.gouv.fr).
} 
todo. Emergem, assim, duas novas concepções de acesso ao direito, a de informação jurídica, até como forma de prevenção do recurso aos tribunais, e a da assistência jurídica, que funciona como uma forma extrajudicial de resolução de conflitos. As inovações desta lei vão, ainda, no sentido de aumentar o apoio jurisdicional nas transacções pré-contenciosas e na mediação penal, na concretização das Casas de Justiça e de Direito e na substituição das formas de assistência judiciária em favor de sistemas de prestação de informações jurídicas. Pretende-se passar de um modelo de "apoio judiciário" para o de "apoio jurídico", de modo a evitar ou a diminuir o recurso aos tribunais.

As estruturas deste modelo de acesso, para além das estruturas judiciais e das formas de resolução extrajudicial de conflitos, asseguradas pela conciliação, arbitragem e mediação, são os Conselhos Departamentais de Acesso ao Direito (CDAD), as Casas de Justiça e de Direito (CJD) e os Pontos de Acesso ao Direito (PAD). A missão dos CDAD é definir uma política e coordenar acções de acesso ao direito no Departamento Administrativo em que está inserido. As CJD visam a prevenção de delinquência, o apoio às vítimas, $\mathrm{o}$ acesso ao direito e o desenvolvimento dos mecanismos alternativos de regulação de conflitos civis e penais. Os PAD são um local de acolhimento gratuito e permanente que presta informação de proximidade sobre os direitos e deveres dos cidadãos com problemas jurídicos ou administrativos. Estas entidades podem funcionar junto dos tribunais, das CJD ou das associações, ${ }^{12}$ de modo a garantir uma proximidade efectiva aos cidadãos com maiores problemas sócio-económicos. O financiamento destas estruturas é essencialmente público (estatal ou local), embora se prevejam e estimulem as parcerias com entidades privadas.

\subsection{A Inglaterra e o País de Gales: o judicare em acção}

O sistema de acesso ao direito em vigor em Inglaterra e no País de Gales foi reformado através da Lei de Acesso à Justiça de 1999 (Lei do Apoio Judiciário). ${ }^{13}$ Esta lei prevê a existência da Comissão de Apoio Judiciário (CAJ), com delegações regionais e com competência para a coordenação das várias fontes de financiamento dos serviços públicos de apoio judiciário (os advogados, as agências de aconselhamento e as autoridades locais). As entidades

\footnotetext{
12 As associações associadas aos CDAD passaram, nos últimos anos, a apoiar os mais necessitados, quer na divulgação dos seus direitos, quer na sua defesa (questões de consumo, de ambiente, de habitação, de minorais étnicas, etc.). Estas associações contribuem, assim, para uma verdadeira política local de acesso ao direito.

${ }_{13}$ Cf. o relatório da Comission de Réforme de l'Accès au Droit et à la Justice (2001) e os relatórios inseridos no site do Lord Chancellor's Department (www.open.gov.uk/lcd).
} 
prestadoras de serviços jurídicos, no âmbito da política de acesso ao direito e à justiça, são reconhecidas pela CAJ, que atribui um certificado de qualidade a todas as organizações que celebrem contratos públicos com essa Comissão. No apoio judiciário em matéria penal, o Serviço de Defesa Criminal da CAJ reconhece a necessidade de contratualizar esse serviço com os advogados que possam prestar serviços de aconselhamento, de assistência ou de representação dos arguidos. Os financiamentos são públicos e a CAJ responde directamente perante o Parlamento.

O apoio é concedido apenas a particulares, não existindo um critério de nacionalidade ou de domicílio. A atribuição de apoio em matéria cível depende de uma dupla condição: do património e do rendimento do requerente, do cônjuge ou de pessoa com quem viva em união de facto. ${ }^{14}$

\subsection{A Espanha: um sistema de assistência judiciária gratuita}

O sistema de acesso ao direito e à justiça em Espanha foi alterado em 1996, uma década após a abolição das taxas judiciais. ${ }^{15} \mathrm{O}$ conceito do direito a assistência jurídica e judiciária gratuita configura, agora, um sistema mais completo e, portanto, com mais garantias de igualdade processual das partes. Tal sistema prevê, ainda, serviços de consulta e de orientação jurídica prévia ao início do processo, de modo a prevenir os litígios, bem como o apoio pericial e a redução substancial dos custos na obtenção de escrituras e de outros documentos notariais.

Em Espanha existe um duplo requisito para conceder assistência jurídica gratuita: um critério objectivo, baseado na situação económica do requerente, complementado com um critério flexível de apreciação subjectiva. Este último possibilita o reconhecimento excepcional do direito a pessoas cuja situação económica exceda os limites legais, desde que, por determinadas circunstâncias, a concessão de apoio judiciário seja recomendável. A decisão passa, agora, pelos Colégios Profissionais, que analisam os pedidos iniciais e decidem provisoriamente, e pelas Comissões de Assistência Jurídica Gratuita ${ }^{16}$, como órgãos formalmente responsáveis pela decisão final, em cuja composição se encontram representadas as instâncias intervenientes no processo (tribunal, advogados, procuradores, segurança social).

O Ministério da Justiça e o Ministério do Interior disponibilizarão o apoio administrativo e técnico e as Ordens dos advogados e procuradores colo-

\footnotetext{
${ }^{14}$ Este rendimento e património não são considerados se houver conflito de interesses.

${ }^{15}$ Cf. a Ley de Assistencia Jurídica Gratuita (Lei 1/1996, de 10 de Janeiro) e o site do Ministério da Justiça (htpp://www.mtu.es).

${ }_{16}$ As Comissões de Assistência Jurídica Gratuita estão sediadas em cada capital de província, mas, caso o volume de solicitações o justifique, poderão criar-se delegações das Comissões.
} 
cam à disposição uma lista dos juristas inscritos para prestar serviço nas comissões, indicando as especialidades, quando as haja. O financiamento é público, mas gerido pelos colégios profissionais. A remuneração dos profissionais obedece a uma tabela, elaborada pelos ditos colégios profissionais, segundo uma tipologia de actos.

\section{O acesso ao direito e à justiça em Portugal: também um regime legal de assistência judiciária gratuita}

\subsection{A evolução do regime jurídico do apoio judiciário: as três rupturas}

A evolução do acesso ao direito e aos tribunais, através do regime jurídico de apoio judiciário, esteve sujeita, nas últimas décadas, a três rupturas. A primeira, em 1970, com a consagração de um regime de assistência judiciária aos mais pobres. A segunda, em 1987, com a entrada em vigor, a partir de Novembro de 1988, de um regime mais alargado de apoio judiciário (informação, consulta e patrocínio jurídico) e a atribuição à Ordem dos Advogados da nomeação de patronos com uma remuneração mais adequada à profissão. A terceira ruptura, em 2000, que entrou em vigor em 1 de Janeiro de 2001, com a desjudicialização do processo e da decisão de atribuição de apoio judiciário e a tentativa de dignificação do patrocínio oficioso, estipulando que a Ordem dos Advogados nomeie apenas advogados (e não estagiários) nos processos em que a lei exige o patrocínio judiciário e melhorando a remuneração dos advogados (patronos e defensores oficiosos) que prestem serviços no âmbito do apoio judiciário.

\subsection{A Constituição da República e o regime do apoio judiciário (1998-2003)}

O direito de acesso aos tribunais e ao direito, previsto no artigo $20 .^{\circ}$ da Constituição da República Portuguesa (CRP), após as revisões de 1982, 1992 e 1997, abarca o direito quer à informação jurídica, quer ao patrocínio jurídico. Gomes Canotilho e Vital Moreira alertaram para o facto de que "é incontestável que esse direito só terá um mínimo de substância na medida em que abranja a possibilidade de recurso, em condições acessíveis, a serviços públicos (ou de responsabilidade pública) de informação jurídica e de patrocínio jurídico, sob pena de não passar de um 'direito fundamental formal'"(Canotilho e Moreira, 1993: 163). ${ }^{17}$

\footnotetext{
17 Aquando da discussão das propostas de alteração da CRP, o deputado Calvão da Silva referiu que no artigo $20{ }^{\circ}$ estava consagrado "um dos grandes direitos ou um direito humano fundamental, visando [...] a terceira vaga, de modo a que nela se veja não só o acesso aos tribunais, propriamente ditos, mas também uma outra vertente mais ampla: trata-se da tutela jurisdicional efectiva".
} 
O instituto do acesso ao direito e aos tribunais compreende, assim, em Portugal, a partir de 1998, em primeiro lugar, a informação jurídica, a protecção jurídica, e, dentro desta, a consulta jurídica e o apoio judiciário. Em segundo lugar, verifica-se a co-responsabilização do Estado e das entidades representativas das profissões forenses, designadamente a Ordem dos Advogados e a Câmara dos Solicitadores, pela implementação e funcionamento. Em terceiro lugar, o Estado assume-se como garante de uma adequada remuneração aos profissionais que intervieram no sistema de acesso ao direito e aos tribunais.

As normas sobre informação jurídica, eram inovadoras. A ideia era alcançar a informação jurídica recorrendo a acções, permanentes e planeadas, através de diversas formas de comunicação, com o fim de tornar o direito e o ordenamento jurídico mais conhecidos e permitir um melhor exercício dos direitos e deveres. ${ }^{18}$

A consulta jurídica foi também uma inovação introduzida pela legislação de 1987. Para concretizar tal forma de protecção jurídica, o Ministério da Justiça, em colaboração com a Ordem dos Advogados, pretendia instalar e assegurar o funcionamento de Gabinetes de Consulta Jurídica, de forma gradual, em todo o território nacional.

As inovações prendiam-se, ainda, com o alargamento do âmbito objectivo do apoio judiciário, que, além da dispensa, total ou parcial, de preparos, do patrocínio oficioso e da dispensa do prévio pagamento de custas compreendia, também, a dispensa e o deferimento do pagamento de custas, o deferimento do pagamento de preparos e a dispensa do pagamento de honorários aos causídicos patrocinantes. ${ }^{19}$

Em meados dos anos noventa, surgiu a Lei n. ${ }^{\circ} 46 / 96$, de 3 de Setembro, que alterou o referido regime jurídico do apoio jurídico. As alterações consistiram, essencialmente, em estender a protecção jurídica a estrangeiros e a apátridas que tivessem requerido a concessão de asilo ao Estado Português, o que deu lugar a várias declarações de inconstitucionalidade material pelo Tribunal Constitucional. ${ }^{20}$

\footnotetext{
${ }^{18}$ No quadro da informação jurídica, era, ainda, inovadora a ideia não concretizada de criar serviços de acolhimento junto dos tribunais e dos serviços judiciários.

19 Terá de ser desenvolvido um juízo de prognose póstuma, de equidade, proporcionalidade e razoabilidade para aferir os encargos da acção, atendendo ao grau de insuficiência económico-financeira do requerente. Permite-se, ainda, o diferimento do pagamento da taxa de justiça e demais encargos com o processo, sempre que do seu pagamento imediato resultar a impossibilidade de recorrer ao tribunal, o que veio relativizar o pressuposto patrimonial da concessão do apoio judiciário.

${ }^{20}$ Relativamente às pessoas colectivas, o apoio judiciário apenas passou a poder ser dispensado àquelas com fins não lucrativos e às sociedades e aos comerciantes em nome individual em situações muito precisas.
} 
O regime de acesso ao direito e aos tribunais foi, ainda, recentemente alterado através da Lei n. ${ }^{\circ}$ 30-E/2000, de 20 de Dezembro, passando a ser da competência dos serviços da Segurança Social a apreciação dos pedidos de concessão de apoio judiciário. Pretendia-se a qualificação do apoio judiciário como um instrumento para o reforço da igualdade de oportunidades e a libertação dos tribunais da excessiva carga administrativa que os onerava, colocando a tramitação do processo junto de um serviço que deveria dispor de melhores e mais completas informações a respeito do requerente.

O patrocínio judiciário, a outra modalidade de apoio judiciário, abrange a nomeação de patrono, o pagamento dos honorários devidos ao patrono nomeado e o pagamento das despesas inerentes ao patrocínio. Assim, os honorários devidos ao patrono escolhido pelo requerente de apoio judiciário são pagos pelo Estado, desde que esse advogado seja aceite e nomeado para o efeito, pela Ordem dos Advogados. ${ }^{21}$

A alteração legal de 2000 veio também melhorar o estatuto remuneratório dos patronos oficiosos. Os advogados, os advogados estagiários e os solicitadores que prestem serviço no quadro do apoio judiciário têm direito a ser remunerados e reembolsados das despesas pelo Estado, não devendo o pagamento dos honorários e o reembolso das despesas aguardar o termo do processo. ${ }^{22}$

A legislação em vigor de apoio judiciário tem em vista proteger, não apenas os mais carenciados economicamente, mas também quem se encontra em situações de desigualdade no recurso aos tribunais por circunstâncias ocasionais.

${ }^{21}$ A competência para a nomeação de patrono pertence à Ordem dos Advogados ou à Câmara dos Solicitadores, e será feita entre advogado, advogado estagiário ou solicitador, no prazo de 10 dias a contar da notificação da decisão final do pedido de apoio judiciário. As regras sobre o pedido de apoio judiciário na modalidade de nomeação de patrono são inovadoras: a notificação da decisão de nomeação do patrono faz uma advertência para o reinício do prazo judicial naqueles casos em que o pedido de apoio judiciário é apresentado durante a pendência da acção; é feita menção expressa ao dever que recai sobre o requerente do pedido de colaborar com o patrono nomeado, cuja falta poderá fundamentar o pedido de escusa. Por outro lado, o patrono é agora obrigado a comunicar à Ordem dos Advogados ou à Câmara dos Solicitadores a propositura da acção, que deverá ocorrer dentro dos 30 dias subsequentes à data da notificação da nomeação.

Se houver três pedidos de escusa, apresentados sucessivamente e sempre com fundamento de "manifesta inviabilidade da pretensão", a Ordem dos Advogados ou a Câmara dos Solicitadores poderão recusar nova nomeação para o mesmo fim.

22 Os honorários devidos por serviços prestados no âmbito do apoio judiciário constam de uma tabela, que será actualizada anualmente, anexa à Portaria n. ${ }^{\circ}$ 150/2002, de 19 de Fevereiro, proposta pela Ordem dos Advogados e pela Câmara dos Solicitadores e aprovada pelo Ministério da Justiça. O encargo com o funcionamento dos diversos gabinetes de consulta jurídica cabe ao Estado, através do Cofre Geral dos Tribunais. 
Em suma, o actual regime legal do apoio judiciário é hoje mais amplo que o existente no quadro de assistência judiciária (1970-1987), abrangendo pessoas singulares e colectivas e, para além da justiça civil, laboral e dos arguidos, na justiça penal ${ }^{23}$, também o assistente por crime público, a vítima ou parte civil, bem como a impugnação da decisão administrativa. No entanto, no presente artigo, ao analisarmos o "direito em acção" privilegiaremos a informação jurídica, a consulta jurídica e o patrocínio oficioso em acções cíveis e laborais, que sofreram um maior impacto com as alterações recentes ao instituto do apoio judiciário. ${ }^{24}$

\section{O acesso ao direito e à justiça em Portugal: o regime do apoio judiciário em acção}

\subsection{A informação, a consulta e a representação jurídica: entre o Estado e a sociedade}

Na investigação que efectuámos (Pedroso, Trincão e Dias, 2002), encontrámos uma pluralidade de formas de acesso dos cidadãos ao direito e à justiça através de entidades, públicas e privadas, que actuam fora do sistema judicial. Esta "quase" rede de serviços jurídicos complementares, em regra desvalorizados ou ignorados, permitem estabelecer uma nova concepção de acesso dos cidadãos ao direito e à justiça onde o papel de um conjunto diversificado de entidades públicas e privadas é bastante importante no reforço e aprofundamento do sistema democrático e, em concreto, no acesso à informação jurídica e à resolução de conflitos através dos meios judiciais e não judiciais, públicos e privados, formais e informais. As entidades públicas analisadas nesta subsecção são de distinta natureza e âmbito de actuação. Atentaremos, a título de exemplo, na acção do Instituto de Desenvolvimento e Inspecção das Condições de Trabalho (IDICT) e na das Juntas de Freguesia. Relativamente às entidades privadas ou que funcionam em parceria, analisaremos, designadamente, a acção de associações, de sindicatos e de centros de arbitragem de conflitos de consumo.

\footnotetext{
${ }^{23}$ As disposições que regulam o apoio judiciário no âmbito do processo penal encontram-se, neste diploma, consagradas de forma autónoma. A regra geral nesta matéria é que a nomeação do patrono e a dispensa de patrocínio, sua substituição e remuneração são feitas nos termos do Código de Processo Penal. A nomeação do defensor oficioso é, geralmente, feita pelo juiz, podendo sê-lo pelo Ministério Público ou por entidade de polícia criminal, nos casos urgentes.

${ }^{24}$ No actual regime de apoio judiciário, o arguido que não constitua advogado nem consiga obter o apoio judiciário, por insuficiência económica, na modalidade de patrocínio judiciário é responsável pelo pagamento dos honorários e despesas com o patrocínio oficioso, mesmo que tenha havido absolvição.
} 


\subsubsection{A administração do Estado e o acesso ao direito: o caso do IDICT}

O Instituto de Desenvolvimento e Inspecção das Condições de Trabalho (IDICT) demonstra um desempenho de grande relevo. Os seus serviços espalhados pelo país e os que integram as Lojas do Cidadão já existentes têm efectuado, em média, 215000 atendimentos gratuitos por ano, na última década. Nos últimos três anos analisados (1998 a 2000), o valor estabilizou em redor dos 200000 atendimentos anuais (Pedroso, Trincão e Dias, 2002). ${ }^{25}$

As consultas mais frequentes dizem respeito ao direito às férias, ao subsídio de férias, às remunerações, aos despedimentos e aos horários de trabalho. A maioria dos consulentes são provenientes dos sectores de actividade relativos ao comércio a retalho, à construção civil, à hotelaria e, mais recentemente, ao serviço doméstico. ${ }^{26}$

Os sectores de actividade mais representados dizem, assim, respeito a áreas em que a fragilidade das relações laborais se manifesta com maior acuidade e nas quais, em regra, os trabalhadores possuem menos habilitações literárias. Assim, a grande procura dos serviços do IDICT permite aos cidadãos informarem-se juridicamente dos seus casos, funcionando como uma primeira instância que esclarece o consulente ou o encaminha para as instâncias mais apropriadas: Ministério Público, sindicatos ou advogados.

\subsubsection{As juntas de freguesia no concelho de Lisboa: um actor inesperado}

Ao nível do Estado local, analisámos a acção das juntas de freguesia dos concelhos de Lisboa e de Coimbra. Enquanto as juntas de freguesia do concelho de Coimbra não disponibilizam serviços de consulta jurídica para os residentes na sua área de competência (apenas uma afirmou fazê-lo), a maioria das juntas de freguesia do concelho de Lisboa respondeu afirmativamente $(92,6 \%)$. Nestes casos, os advogados exercem funções a tempo parcial e os assuntos mais frequentes são os relativos à habitação (inquilinato, condomínios, obras, despejos, etc.) e ao direito de família (divórcios, pensão de alimentos, etc.). A existência destes serviços jurídicos de proximidade não é isenta de controvérsia, dado que a Ordem dos Advogados não reconhece a sua legalidade. No entanto, estes serviços das juntas de freguesia permitem reforçar os meios facilitadores de acesso dos cidadãos ao direito e à justiça, funcionando, também, como um serviço complementar aos mecanismos oficiais e judiciais existentes. ${ }^{27}$

${ }^{25}$ Cerca de $2 / 3$ dos atendimentos são efectuados a trabalhadores e cerca de $1 / 3$ a empregadores.

${ }^{26} \mathrm{O}$ atendimento efectuado pelo IDICT na Loja do Cidadão de Lisboa segue de perto a distribuição nacional e demonstra, pelo número de consulentes recebidos no ano de 2000 (15.124), a importância que este serviço representa.

${ }^{27}$ Um eventual efeito perverso desta acção pode ser o cambão, ou seja, o encaminhamento do consulente para o escritório privado do advogado. 


\subsubsection{As associações patronais, sindicais e cívicas: o seu enorme potencial e muitas debilidades}

As organizações da sociedade apresentam diferentes desempenhos no tocante à prestação de serviços jurídicos, de acordo com a sua natureza e objectivos. Referimos, a título de exemplo, as associações empresariais, os sindicatos e a APAV - Associação de Apoio à Vítima.

As associações empresariais inquiridas prestam, na esmagadora maioria (96,2\%), serviços jurídicos aos seus associados. A sua capacidade é demonstrada, essencialmente, pelo número de consultas anuais, pois $42,4 \%$ efectuaram mais de 100. Cerca de 6\% efectuaram mais de 1.000 consultas anuais. A maioria dos juristas é contratada por avença ou a tempo parcial, mas um terço desses profissionais integra os quadros das associações empresariais. As áreas mais solicitadas estão, naturalmente, relacionadas com as suas actividades económicas, estando em primeiro lugar as questões laborais, seguidas das cíveis e comerciais.

Os sindicatos que responderam ao nosso inquérito possuem, na sua maioria, e à imagem do que constatámos para as associações empresariais, a possibilidade de disponibilizarem serviços jurídicos aos trabalhadores seus associados (97,6\%). Este apoio jurídico é gratuito na fase de informação e de consulta jurídica, podendo ser cobradas algumas despesas processuais no caso de se recorrer aos tribunais (apenas 9,4\% afirmaram cobrar nestes casos). O número de consultas jurídicas efectuadas pelos sindicatos supera o das associações empresariais. Cerca de $32 \%$ dos sindicatos inquiridos efectuaram mais de 300 consultas no ano de 2000 , tendo mesmo $16 \%$ efectuado mais de 1000. Com um número de consultas jurídicas que variou entre as $101 \mathrm{e}$ as 300 , no ano de 2000 , temos $24,1 \%$ dos sindicatos. A maioria dos juristas exerce funções a tempo parcial e os assuntos mais frequentes relacionam-se, naturalmente, com as questões de trabalho.

A APAV é uma organização cívica que presta serviços de apoio a vítimas de crime e aos seus familiares. Possui, actualmente, treze gabinetes descentralizados pelo país onde presta serviços de aconselhamento e de acompanhamento aos utentes que a eles recorrem. Estes serviços são de teor diversificado, consoante as necessidades: psicológico, social e jurídico. O número de solicitações registou um crescimento constante ao longo da última década, começando com 151 processos em 1991 e atingindo os 9.476 em 2001. O contacto principal é estabelecido por via telefónica $(63,1 \%$ no ano 2001), seguido da via presencial (35,3\% em 2001). O principal apoio é feito de uma forma genérica ( $45 \%$ ), seguido do apoio jurídico com $29,2 \%$ (APAV, 2002). Estes valores comprovam a importância da APAV no acesso das vítimas ao direito e à justiça. A sua actuação tem permitido a emer- 
gência de situações que, normalmente, não chegariam aos tribunais, funcionando também como um serviço jurídico complementar de grande valor. $^{28}$

\subsubsection{Os consumidores e o acesso ao direito e à justiça: as associações, as parcerias e a acção municipal}

A defesa dos consumidores, para além do Estado (Instituto do Consumidor), apresenta diferentes respostas relativamente ao acesso ao direito e à justiça dos consumidores. A DECO é a maior associação nesta área em Portugal, com os seus cerca de 260 mil associados. O número de reclamações recebido entre 1998 e 2001 regista, no entanto, um decréscimo acentuado, apenas invertido no último ano considerado. Assim, das 7280 reclamações recebidas em 1998, chegamos às 3862 de 2001 . A maioria dos pedidos de informação é efectuada por via telefónica referindo-se, no ano de 2001, principalmente à prestação de serviços, designadamente, aos serviços públicos, aos serviços financeiros/seguros, às vendas forçadas, ao turismo e aos veículos. Mais recentemente, a DECO iniciou a criação de Gabinetes de Apoio e Acompanhamento ao Endividado (em 2001 existiam sete), procurando disponibilizar meios extrajudiciais de resolução de conflitos nesta área.

Os Centros de Arbitragem de Conflitos de Consumo são hoje, essencialmente, associações criadas por impulso da União Europeia e do Estado, resultantes de parcerias entre as associações de consumidores, de comerciantes e das autarquias, que desempenham, igualmente, uma função importante na área dos conflitos de consumo. Embora existam 16 Centros de Arbitragem inseridos nas estatísticas do Ministério da Justiça, apenas 11 apresentaram dados nos anos de 1999 e 2000. No período de 1997 a 2000, registou-se um crescimento no número de informações prestadas, passando de 6502 para 9416. A principal via de contacto é telefónica, embora a presencial também registe valores consideráveis. A percentagem de processos findos após resolução (arbitragem, mediação e conciliação) é bastante importante, demonstrando as potencialidades destes meios extrajudiciais de resolução de conflitos. Estes serviços jurídicos complementares e integrados (da informação à resolução do litígio) demonstram, assim, uma grande utilidade, embora o seu número, diversidade temática e distribuição regional seja ainda bastante limitado. No entanto, permite resolver confli-

${ }^{28}$ Em Pedroso, Trincão e Dias (2002) analisámos, ainda, a acção das associações de defesa dos direitos dos imigrantes e de defesa do património e do ambiente, que têm estruturas de apoio jurídico muito débeis, o que está correlacionado com a fragilidade associativa dessas áreas de intervenção cívica. 
tos ou prestar informações jurídicas em situações que, normalmente, não chegariam a outras instâncias oficiais (Pedroso, 2001; 2002).

Os Centros de Informação Autárquica ao Consumidor, que funcionam nos Municípios, são, actualmente, 54, distribuídos pelo território nacional. Estes Centros receberam, em 2001, cerca de 1500 reclamações relacionadas, principalmente, com a área dos serviços, com particular incidência na área das telecomunicações. Estas estruturas encontram-se numa fase mais embrionária e menos consolidada do que as duas anteriores, demonstrando, assim, um desempenho mais baixo. Não deixa, contudo, de apresentar potencialidades de afirmação, podendo efectuar um serviço jurídico complementar bastante importante no que respeita à prestação de informação e de consulta jurídica aos cidadãos e, desse modo, contribuir para a melhoria do acesso ao direito e à justiça.

\subsubsection{As potencialidades e limites desta rede quase-informal de serviços jurídicos gratuitos}

Da análise efectuada, resultou um conjunto de conclusões gerais e transversais às várias experiências nacionais estudadas de serviços jurídicos complementares na promoção do acesso dos cidadãos ao direito e à justiça. Em primeiro lugar, essa análise permite-nos afirmar que a diversidade das entidades prestadoras de serviços jurídicos complementares de apoio aos cidadãos demonstra uma maior vitalidade do que se pressupunha inicialmente. Além disso, esta diversidade de entidades não está associada ao sistema de justiça oficial nem se encontra só na esfera do Estado, antes demonstrando uma multiplicidade de tipologias: estaduais (centrais ou locais); profissionais; semi-profissionais ou semi-voluntárias; e voluntárias. Em segundo lugar, a existência, dentro do Estado, de uma rede de entidades públicas que presta informação jurídica concreta não está articulada entre si e/ou com o sistema judicial ou não judicial de resolução de conflitos, nem está, à partida, vocacionada para o desempenho "natural" dessas funções, testemunhando, ainda, falta de informação sobre a sua "arquitectura", competências, funções, localização e composição. Em terceiro lugar, conclui-se que existe uma enorme disparidade de meios e de recursos entre os vários casos analisados. Esta disparidade proporciona desempenhos muito desequilibrados entre si. Assim, e apesar de a vontade de possuir serviços jurídicos ser relativamente consensual nos estudos de caso analisados, a possibilidade de prestá-los está directamente relacionada com os meios financeiros e logísticos disponíveis por cada uma das entidades estudada.

Em consequência, podemos afirmar que esta disparidade de meios proporciona uma desigualdade, quer de desempenho, quer de acesso dos 
cidadãos ao direito e à justiça. No que respeita às associações emergentes da sociedade civil, podemos vislumbrar vários níveis de desigualdade: económicos e sociais, entre as associações empresariais e os sindicatos; entre causas de interesse público e colectivo, com o predomínio de fortes associações de defesa dos consumidores e das vítimas de violência em detrimento das que defendem o ambiente e património e os direitos dos imigrantes; e com os cidadãos que possuem melhor informação e meios sócio-económicos a activar mais facilmente os mecanismos ao seu dispor. No entanto, apesar das dificuldades existentes na maioria dos casos analisados, observa-se um aumento da procura destes meios de acesso, bem como da sua capacidade de resposta.

Da análise efectuada, resulta, ainda, que o desenvolvimento de um sistema integrado de acesso ao direito e à justiça não pode ignorar a acção destas entidades públicas e privadas, que funcionam como um facilitador da informação jurídica, da consulta jurídica e até da prevenção e resolução de litígios. A dimensão encontrada permite-nos concluir pela existência de uma rede não orgânica e quase-informal de serviços jurídicos complementares àqueles que normalmente são reconhecidos como integradores do sistema de apoio judiciário, ou seja, a informação e a consulta jurídica prestada pela Ordem dos Advogados e pelo Ministério Público.

\subsection{A acção do Ministério Público: a defesa dos trabalhadores, das crianças e dos interesses colectivos}

A actividade do Ministério Público desempenha um importante papel como facilitadora do acesso ao direito e à justiça. Este actor do sistema judicial português tem como competências, para além da área penal em que consiste a sua principal área de intervenção, a defesa dos incapazes, incertos e ausentes, o exercício do patrocínio oficioso dos trabalhadores, dos menores e a defesa dos interesses colectivos e difusos.

No estudo por nós conduzido e ao qual nos vimos reportando, procedemos a uma análise da intervenção do Ministério Público nos conflitos de trabalho e nos conflitos de família e menores. Nas acções de contratos individuais, verifica-se um aumento do número de processos entrados e findos, o que demonstra a importância do papel do Ministério Público que continua a ser um grande mobilizador deste tipo de acções. Das estatísticas da justiça, através dos verbetes das acções findas, concluímos que o Ministério Público em 1998, 1999, 2000 e 2001, patrocinou, respectivamente, 29,3\%, $29,5 \%, 25,2 \%$ e $19,8 \%$ das acções de contratos individuais de trabalho que terminaram nesses anos. 
As acções referentes a acidentes de trabalho também registam um aumento do total de processos distribuídos e findos no ano. Porém, o que merece ser sublinhado é o número dessas acções em que o Ministério Público intervém a título de patrono: em 1998, 9374 (92,7\%); em 1999, 10072 (92,4\%); em 2000, 11039 (92,8\%); e, em 2001, 12091 (91,9\%). Assim, o Ministério Público revela-se um importante facilitador do acesso ao direito do trabalho.

Os dados do serviço de atendimento ao público relativos a contratos individuais de trabalho e a acidentes de trabalho prestados pelo Ministério Público no Tribunal de Trabalho de Coimbra, assumem algum relevo. $\mathrm{Na}$ verdade, foram atendidos nos anos de 1998, 1999, 2000 e 2001, respectivamente, 1475, 2168, 13151 e 927 trabalhadores. Assim, podemos afirmar que, em primeiro lugar, o Ministério Público desempenha um relevante papel como "conciliador informal", nas situações em que o conflito terminou com um acordo entre as partes, e, em segundo lugar, que o serviço de atendimento representa uma percentagem importante do total de acções laborais (CIT e AT) entradas no Tribunal do Trabalho de Coimbra. ${ }^{29}$

A análise do papel do Ministério Público na promoção do acesso nos Tribunais de Família e Menores revela-se especialmente nas acções relativas à regulação do poder paternal: 13422 processos em 1998, 13498, em 1999 e 15437 em 2000. Assim, o Ministério Público foi o autor em 16\% (2485) das acções de regulação do poder paternal no ano 2000, subindo a cerca de $90 \%$ nos casos de incumprimento ou de alteração da regulação do poder paternal, ou seja, nos casos em que um dos pais não cumpre voluntariamente a decisão da regulação do poder paternal ou em que recusa injustificadamente que seja alterada.

Os elementos fornecidos pelos serviços do Ministério Público junto do Tribunal de Família e Menores de Lisboa relativos ao número de processos

\footnotetext{
${ }^{29}$ A questão do patrocínio judiciário, da informação e da consulta jurídica prestada pelo Ministério Público aos trabalhadores constitui um dos pontos mais controversos entre os vários operadores judiciais. No painel do debate que efectuámos (Pedroso, Trincão e Dias, 2002), no qual se abordou o tema, esgrimiram-se argumentos. A favor de que o Ministério Público deixe de dar informação jurídica e de representar os trabalhadores, invocou-se a actual falta de recursos do Ministério Público, a necessidade de recentrar o Ministério Público nas suas funções de magistrado e a desigualdade entre o Ministério Público e um advogado na representação dos trabalhadores, já que ele assume uma dupla função de advogado e de autoridade judicial, o que influencia simbolicamente os litigantes. A favor da manutenção do actual modelo argumentou-se, essencialmente, com o potencial de prevenção e de conciliação de litígios existente na acção do Ministério Público, a falta de alternativas credíveis às quais os trabalhadores carenciados economicamente e não sindicalizados possam recorrer, o bom desempenho do actual sistema e a necessidade de que o Ministério Público continue nos tribunais de trabalho a desempenhar todas as suas outras funções, designadamente nos acidentes de trabalho e no processo executivo.
} 
administrativos entrados, de acções propostas e de atendimentos ao público permitem-nos verificar que esse serviço é fundamental. Na verdade, por exemplo, em 1999, foram realizados 2543 atendimentos contra 1326 processos administrativos e 1019 acções propostas. Assim, sem os serviços prestados no atendimento ao público e no patrocínio das acções tutelares respectivas, em regra, as relativas à regulação do poder paternal, muitos desses litígios seriam "reprimidos" e não teriam, por ora, qualquer solução.

\subsection{Os gabinetes de consulta jurídica da Ordem dos Advogados: uma missão não cumprida}

O aparecimento do primeiro Gabinete de Consulta Jurídica (GCJ) deu-se em Lisboa, em 18 de Março de 1974, mas a sua implantação desenvolveu-se de forma gradual, em particular a partir de 1991, a um ritmo muito mais lento do que os discursos afirmavam.

A criação dos Gabinetes de Consulta Jurídica foi efectuada de forma casuística, quer no tocante à cobertura territorial, que é limitada, quer no que respeita às garantias das condições mínimas de funcionamento. A sua criação deveu-se, na maioria dos casos, à iniciativa das delegações da Ordem dos Advogados, ou seja, dos seus dirigentes locais, normalmente com o apoio das Câmaras Municipais que, posteriormente, vieram a não assegurar os meios financeiros, humanos e logísticos que garantiam um funcionamento permanente, eficaz e visível. A maioria dos gabinetes funciona apenas num período muito limitado da semana, nomeadamente, duas a seis horas semanais, em horários, em regra, muito variados e pouco adaptados aos ritmos dos cidadãos. ${ }^{30}$

Outro factor que contribui para este desequilíbrio relaciona-se com o universo de advogados potencialmente disponíveis para colaborar com os Gabinetes de Consulta Jurídica, que difere bastante em termos de distribuição nacional, com variações que vão dos cinco aos 960 advogados/ advogados estagiários inscritos para fazerem escala nos Gabinetes de Consulta Jurídica, respectivamente em Angra do Heroísmo e em Lisboa. Acresce a estas limitações, a deficiente divulgação da sua existência, da actividade e das competências dos Gabinetes de Consulta Jurídica junto dos cidadãos com maiores dificuldades sócio-económicas, devido, entre outras razões, às poucas disponibilidades financeiras, ao pouco envolvimento/empenho das entidades promotoras e aos horários praticados.

\footnotetext{
${ }^{30}$ Apenas seis gabinetes asseguram um funcionamento diário, ainda que alguns destes o façam a meio tempo. Nos restantes, observa-se uma diversidade de horários enorme, existindo ainda um gabinete que apenas funciona se, antecipadamente, houver lugar a solicitação/marcação.
} 
Existe um paradoxo performativo, no que diz respeito ao desempenho dos Gabinetes de Consulta Jurídica. A par de um aumento constante do número de Gabinetes de Consulta Jurídica, regista-se um decréscimo, igualmente constante, do número de consultas jurídicas prestadas a cidadãos (com a ligeira excepção do ano 2001). Perante os resultados apresentados, podemos afirmar que a existência de alguns Gabinetes de Consulta Jurídica é meramente legal e aparente, mas não real. ${ }^{31}$

Os advogados e dirigentes que prestam serviços nos GCJ destacam como causas do mau desempenho a falta de formação para esta actividade específica e o valor reduzido que recebem como remuneração. Além disso, consideram que a impossibilidade de acompanharem o processo, em termos de consultas jurídicas, faz com que o cidadão possa ser confrontado com opiniões muito diferentes, para não dizer opostas. Acresce, ainda, a não articulação entre a actividade dos gabinetes e a acção dos patronos oficiosos nomeados pela Ordem dos Advogados.

\section{4. $O$ acesso aos tribunais e o novo regime jurídico do apoio judiciário: a cidadania e as perversões}

\subsubsection{A duplicação dos pedidos de apoio judiciário: a cidadania e o interesse dos advogados dos beneficiários}

Em 1 de Janeiro de 2001, entrou em vigor a Lei n. ${ }^{\circ}$ 30-E/2000, de 20 de Dezembro. Operou-se, desta forma, uma desjudicialização do processo de apoio judiciário, que passou a constituir, como já referimos, um procedimento administrativo, sem prejuízo de estar reservada à Ordem dos Advogados a competência para nomear o patrono e de o financiamento ser assegurado pelo Ministério da Justiça.

O desempenho da Segurança Social e da Ordem dos Advogados é fundamental para uma aplicação adequada da nova lei. Enquanto a Segurança Social iniciou, no final de 2000 e no início de 2001, a contratação e a instalação dos seus serviços de instrução e de decisão dos processos de apoio judiciário, a Ordem dos Advogados só muito mais tarde se adaptou às necessidades decorrentes do novo regime. No entanto, em 2001, foi visível "a juventude" e a dificuldade de resposta dos serviços de Segurança Social.

\footnotetext{
${ }^{31} \mathrm{O}$ caso mais flagrante, devido ao enorme peso que detém no cômputo geral dos Gabinetes de Consulta Jurídica, é o de Lisboa, que vem registando, ao longo da última década, um decréscimo quase constante do número de consultas prestadas (em 1984, efectuou 4504 e, em 2001, apenas 2130). Verifica-se o mesmo decréscimo, embora em termos mais ligeiros, noutros gabinetes com uma actividade destacável, como é o caso de Porto/Matosinhos ou de Ponta Delgada.
} 
Inesperadamente, em 2001, os requerimentos de apoio judiciário entrados na Segurança Social, em Portugal continental, atingiram o número de 103965, o que significou que a procura mais do que duplicou de 2000 para 2001, o que é consentâneo com a informação dos Conselhos Distritais da Ordem dos Advogados, que também referem que os pedidos de nomeação de patrono representaram sensivelmente o dobro no ano de 2001.

Ora, considerando que os requerimentos de apoio judiciário representam 20,8\% das acções declarativas cíveis e de trabalho entradas em 2001 (cf. Estatísticas da Justiça, 2001), podemos concluir que os pedidos de apoio judiciário assumem já um significado importante no conjunto da litigação judicializada.

Em Portugal continental, a Segurança Social não concedeu 13477 dos requerimentos de apoio judiciário, ou seja, cerca de $13 \%$. Quase metade dos requerimentos $(46551-44,7 \%)$ foram apresentados nos distritos do Porto (24634) e de Lisboa (21917), em razão inversa à população de cada um dos distritos. Os restantes dezasseis distritos do continente registaram $57414(55,2 \%)$ pedidos de apoio judiciário. ${ }^{32}$ Constata-se, assim, uma relação entre a urbanização e um maior número de requerimentos de apoio judiciário.

Esta explosão de pedidos de apoio judiciário admite-se que tenha uma tripla causa: a primeira, a grande divulgação mediática da medida; a segunda, a proximidade dos cidadãos à rede de cerca de 500 postos de atendimento da Segurança Social e a facilidade em aí efectuarem os seus requerimentos, em contraste com os tribunais; a terceira, a indução ao pedido efectuada pelos próprios serviços da Segurança Social e pelos advogados dos requerentes que, assim, pretendem aliviar as despesas judiciais dos seus clientes e assegurar a sua remuneração pelo Estado.

\subsubsection{A reacção da Ordem dos Advogados: a luta por um papel quase exclusivo no apoio judiciário}

No desempenho do novo processo de apoio judiciário, a Ordem dos Advogados considera, nos documentos que elaborou, o seguinte: a) que se verificou um crescimento de trabalho e de custos administrativos para os quais não estava preparada, pelo que considera que o Ministério da Justiça lhe deve financiar essa actividade; b) a Segurança Social, por um lado, incita à proposição de acções inviáveis e a que os cidadãos solicitem a nomeação

\footnotetext{
32 A dispensa total de taxa de justiça e o pagamento de honorários do patrono são as modalidades mais relevantes, representadas na amostra de dezasseis distritos, sendo respectivamente, de 96,1\% e de $35,2 \%$ do total deste universo, coincidindo, em regra, a segunda modalidade com a primeira.
} 
de patrono, por outro lado, não distingue entre acções a propor e acções pendentes e, ainda, não sabe avaliar a suficiência e insuficiência económica dos requerentes; c) os honorários são, em regra, baixos e pagos com muito atraso, o que afecta especialmente os jovens advogados e os da área metropolitana de Lisboa e do distrito de Setúbal (o distrito - fora de Lisboa e Porto - em que mais é requerida a nomeação de patrono com pagamento de honorários); d) há, ainda, problemas de interpretações desencontradas de diversas normas da lei.

As entrevistas efectuadas ao Bastonário e a dois advogados dos corpos sociais da Ordem permitem-nos salientar que, em sua opinião, os principais problemas do actual regime do apoio judiciário são os seguintes: desenvolveu-se o "cambão"; os critérios de decisão da Segurança Social não são adequados; é necessária a escusa de três advogados para a Ordem poder recusar o patrocínio; devia haver uma apreciação da plausibilidade jurídica da pretensão; não existe articulação entre Gabinetes de Consulta Jurídica, a Segurança Social e a Ordem dos Advogados; há uma necessidade urgente de melhorar a defesa oficiosa em processo penal; e seria, ainda, de admitir a possibilidade de qualquer sócio numa sociedade de advogados poder efectuar o patrocínio oficioso em nome da sociedade.

Nas mesmas entrevistas, enunciaram-se as seguintes propostas de reformas: a informação e a consulta jurídica devem ser exclusivas da relação advocatícia; o processo de decisão do apoio judiciário não deve voltar aos tribunais; há que definir as condições económicas de acesso dos requerentes ao apoio judiciário e o critério de plausibilidade ou de viabilidade da acção como condição da concessão de patrocínio judiciário; há que melhorar o desempenho da Ordem dos Advogados, melhorar a articulação com os gabinetes de consulta jurídica e dignificar a defesa oficiosa; e, ainda, criar um Instituto de Acesso ao Direito, que poderá ser meramente advocatício ou de espectro mais largo, em que participem a Ordem dos Advogados ou outras entidades, bem como, proceder à criação de um Fundo de Acesso ao Direito para autofinanciar, mesmo que parcialmente, o sistema de acesso ao direito e à justiça.

A Ordem dos Advogados pretende, assim, vir a conseguir um papel mais preponderante no âmbito do apoio judiciário.

\subsection{3. $O$ positivo, o negativo e as perversões do apoio judiciário em acção em 2001}

O facto de as tarefas antes confiadas ao juiz, ao Ministério Público e aos funcionários judiciais deixarem de os ocupar, na sequência da transferência de competências para a Segurança Social, foi positivo. Um factor que era 
indutor de grande morosidade processual antes do actual regime de acesso ao direito, era a suspensão dos prazos judiciais que estavam em curso aquando da formulação do pedido de apoio judiciário. Tal já não ocorre, sendo o prazo de trinta dias para decisão o responsável pela notória agilização processual.

Assistiu-se a um considerável aumento de pedidos de pagamento de honorários a patrono escolhido, após a entrada em vigor da Lei n. ${ }^{\circ} 30-\mathrm{E} / 2000$, de 20 de Dezembro, o que poderá explicar-se pelo significativo aumento dos honorários previstos para o patrocínio oficioso.

No entanto, foram, ainda, detectados alguns problemas relacionados, por um lado, com a falta de informação prestada aos requerentes de apoio judiciário na formulação dos pedidos, designadamente no preenchimento dos formulários e na deficiente informação, que pode implicar a apresentação de pedidos na Segurança Social por arguidos em processo penal, cujos requerimentos devem ter lugar junto dos tribunais. Por outro lado, constatou-se que não existe concertação entre os Gabinetes de Consulta Jurídica, a Segurança Social e a nomeação de patronos.

Acresce, ainda, o sistemático incumprimento do prazo de dez dias, previsto na lei, para a nomeação de patrono pela Ordem dos Advogados, bem como o caso de nomeações de advogados estagiários para o patrocínio oficioso de causas para as quais não têm competência estatutária, designadamente para acções cíveis cujo valor é superior à alçada dos tribunais de primeira instância e, sobretudo, em processos criminais.

É de registar, ainda, a constatação de três exemplos de perversões detectadas em consequência da aplicação do novo regime de apoio judiciário. A primeira resulta da colisão ou não articulação entre a Segurança Social, o Ministério Público e/ou os advogados escolhidos pelos requerentes, em que a Segurança Social solicita à Ordem dos Advogados a nomeação de um patrono quando o requerente pretende ser representado pelo Magistrado do Ministério Público, em acções de trabalho, ou pelo advogado escolhido por si ou do sindicato ou associação a que pertence. Nestes casos, verifica-se, com frequência, a "concorrência" entre dois patronos para a mesma acção. A segunda perversão resulta de se imputar a alguns serviço de Segurança Social a nomeação como patronos de advogados, directa ou indirectamente, relacionados com esse serviço público. A terceira constatação consiste no facto de ser recorrente a afirmação de que advogados, designadamente de sindicatos, requerem o apoio judiciário para os seus patrocinados com o objectivo de verem pago o seu trabalho através da avença do sindicato acrescido da remuneração que virão a receber do Estado na sua veste de patronos oficiosos. 


\section{Conclusão: a justiça tão perto e tão longe}

A concluir, parece-nos de salientar o impacto positivo da desjudicialização do processo de apoio judiciário. No entanto, há novas questões que nos são colocadas e que resultam, designadamente, da explosão de um crescimento estrutural da procura e da necessidade de repensar os critérios de elegibilidade e de acesso ao sistema, bem como da necessidade de reconfiguração das funções e das competências dos serviços do Estado, da Segurança Social, da Ordem dos Advogados e das entidades da sociedade civil que participem ou venham a participar no novo regime de acesso ao direito e à justiça.

A reforma em curso do regime de apoio judiciário não pode deixar de considerar as dinâmicas do Estado e da sociedade, analisadas neste artigo, que constituem uma rede de entidades prestadoras de serviços jurídicos e que demonstram que o regime do acesso ao direito e à justiça não pode ser confinado a uma visão estrita e limitada de apoio aos mais carenciados economicamente com o único objectivo de que estes possam defender os seus direitos através de uma acção judicial. Acresce, em nosso entender, e de acordo com a nossa investigação, que a Ordem dos Advogados deverá ter um papel importante no sistema de apoio judiciário, mas que não pode apagar ou substituir o papel do Estado e da sociedade.

O novo sistema de acesso ao direito e à justiça deverá ter, por um lado, um novo figurino institucional e jurídico que integre todas as respostas existentes e a criar, no âmbito da informação, da consulta e do patrocínio jurídico e ainda de entidades não judiciais que previnam ou que resolvam litígios. Por outro lado, o novo sistema deve ser construído de modo a que, no respeito pela independência da profissão dos advogados, se conceda às funções do regime de apoio judiciário alguma continuidade temporal, de modo a que possam desempenhar essas funções com a devida formação, qualidade, adequadamente remuneradas e sujeitas a um controlo externo, por uma entidade à qual sejam atribuídas essas competências.

O acesso ao direito e à justiça em Portugal, apesar de tudo, está aqui tão perto... e ainda tão longe!

\section{Referências Bibliográficas}

Associação Portuguesa de Apoio à Vítima (2002), Relatório de Actividades - 2001 (http:/ /www.apav.pt).

Bellow, Gary (1984), "L'aide judiciare aux pauvres - rapport américain”, in Mauro Cappelletti (org.), Accès à la Justice et Etat-Providence. Paris: Publications de l'Institut Universitaire Européen. 
Blankenbourg, Erhard; Cooper, Jeremy (1982), Legal Aid and Services for the Poor in Western Europe: An Annotated Bibliograpby and General Comments. Madison: Law School of the University of Wisconsin.

Blankenbourg, Erhard (1984), "Possibilité de transplanter d'un pays à un autre les expériences touchant l'accès à la justice. Ses limites”, in Mauro Cappelletti (org.), Accès à la Justice et Etat-Providence. Paris: Publications de l'Institut Universitaire Européen.

Canotilho, Gomes J. J. ; Moreira, Vital (1993), Constituição da República Portuguesa. Coimbra: Coimbra Editora ( $3^{a}$ edição).

Carlin, J. ; Howard, J. (1965), "Legal Representation and Class Justice”, U.C.L.A. Law Review, 12, 381.

Caplowitz, D. (1963), The Poor Pay More. New York: Free Press.

Cappelletti, Mauro; Garth, Brian (orgs.) (1978), Access to Justice: A World Survey. Alphen aan den Rijn: Sijthoff and Noorhoff:.

Cappelletti, Mauro (org.) (1981), Access to Justice and the Welfare State. Florence: European University Institute.

Comissão das Comunidades Europeias (2000), Livro Verde: Assistência judiciária em matéria civil : problemas com que se deparam os litigantes em processos transfronteiriços. Bruxelas: Comissão Europeia.

Comissão das Comunidades Europeias (2002), Livro Verde: Sobre os modos alternativos de resolução dos litígios em matéria civil e comercial. Bruxelas: Comissão Europeia.

Comission de Réforme de l'Accès ao Droit et à la justice (2001), Rapport sur la Réforme de l'Accès au Droit et à la Justice. Paris: Ministère de la Justice.

Cooper, Jeremy (1991), Key Guide to Informations Sources in Public Interest Law. London/ New York: Mansell.

Galanter, Marc (1984), "La justice ne se trouve pas seulement dans les décisions des tribunaux”, in Mauro Cappelletti (org.), Accès à la Justice et Etat-Providence. Paris: Publications de l'Institut Universitaire Européen.

Instituto do Consumidor (2002), Revista Consumidores, 117.

Paterson, Alan; Goriely, Tamara (orgs.) (1996), Resourcing Civil Justice. Oxford: United Press.

Pedroso, João (2001), “A construção de uma justiça de proximidade: o caso dos Centros de Arbitragem de Conflitos de Consumo", Revista Crítica de Ciências Sociais, 60, 33-60.

Pedroso, João (2002), Entre a União Europeia e a sociedade portuguesa: a protecção e a resolução dos litígios dos consumidores - o caso da arbitragem de conflitos de consumo em Portugal. Coimbra: Faculdade de Economia da Universidade de Coimbra (diss. de mestrado).

Pedroso, João; Trincão, Catarina; Dias, João Paulo (2001), Percursos da informalização e da desjudicialização - por caminhos da reforma da administração da justiça (análise 
comparada). Coimbra: Centro de Estudos Sociais/Observatório Permanente da Justiça Portuguesa.

Pedroso, João; Trincão, Catarina; Dias, João Paulo (2002), O acesso ao direito e à justiça: um direito fundamental em questão. Coimbra: Centro de Estudos Sociais/Observatório Permanente da Justiça Portuguesa.

Regan, Francis et al. (1999), The Transformation of Legal Aid: Comparative and Historical Studies. Oxford: Oxford UP.

Research and Documentation Center of the Dutch Ministry of Justice (WODC) (1998), Dutch Legal Aid Subsidy Reconsidered: An Evaluation Study of Legal Reform and Access to Law. Amsterdam: Dutch Ministry of Justice.

Santos, Boaventura de Sousa (1985), "Estado e sociedade na semiperiferia do sistema mundial: O caso português”, Análise Social, 87/88/89, 869-901.

Santos, Boaventura de Sousa (1994), Pela mão de Alice. O social e o político na pós-modernidade. Porto: Afrontamento.

Santos, Boaventura de Sousa et al. (1996), Os tribunais nas sociedades contemporâneas: o caso português. Porto: Afrontamento.

Santos, Boaventura de Sousa; Mendes, José; Gomes, Conceição (2003), Inquérito sobre as representações sociais dos tribunais, o direito e a litigiosidade (no prelo).

Sousa, João Ramos de (1993), “A economia política do apoio judiciário”, Sub Judice, 5 , 39-45.

Zander, Michael (1984), "La première vague”, in Mauro Cappelletti (org.), Accès à la Justice et Etat-Providence. Paris: Publications de l'Institut Universitaire Européen.

\section{Endereços electrónicos:}

http://www.echr.coe.int/Fr/FDocs/OBJET\%20DES\%20AFFAIRES2002.pdf

(Conselho da Europa, Tribunal Europeu dos Direitos Humanos, Acórdãos de 2002).

http://www.open.gov.uk/lcd (Lord Chancellor's Department).

htpp://www.mtu.es (Ministério da Justiça de Espanha).

http://www.justice.gouv.fr (Ministério da Justiça da França). 